IJIF

9,2

\section{0}

Received 8 August 2017 Revised 21 August 2017 24 August 2017

Accepted 24 August 2017

\title{
Financial reporting of intangible assets in Islamic finance
}

\author{
Syed Musa Alhabshi
}

Institute of Islamic Banking and Finance, International Islamic University Malaysia, Kuala Lumpur, Malaysia

Hafiz Majdi Ab Rashid

Department of Accounting, International Islamic University Malaysia, Kuala Lumpur, Malaysia

Sharifah Khadijah Syed Agil Centre of Professional Accountancy, INTEC Education College, Selangor, Malaysia, and

Mezbah Uddin Ahmed

Department of Research Affairs, International Shari'ah Research Academy for Islamic Finance, Kuala Lumpur, Malaysia

\begin{abstract}
Purpose - This paper aims to address the financial reporting dimensions of intangible assets with specific reference to International Accounting Standards (IAS) 38 as well as relevant International Financial Reporting Standards (IAS 38 exclusion) that are embedded within intangible assets. These have implications for Islamic financial assets with identifiable and measurable intangible components.

Design/methodology/approach - The study uses the qualitative research method by way of interviews followed by focus group discussions with professional accountants/accounting academics and Sharīah scholars/advisors from academia, the industry and regulatory bodies. Analysis of relevant literature is made to understand the subject matter and Shari' ah-related issues.

Findings - The study observes that the accounting dimensions of tangible assets are generally consistent with Shar'̄'ah requirements. However, significant variation arises when the dimensions of intangible assets are represented in financial assets.

Research limitations/implications - The paper presents an exploratory in-depth analysis within the context of intangible assets as specified in IAS 38 .

Originality/value - The paper elucidates the comparative accounting dimensions and Sharīah requirements in reporting financial assets.
\end{abstract}

Keywords Financial reporting, intangible assets, Islamic finance, financial assets

Paper type Research paper

(C) Syed Musa Alhabshi, Hafiz Majdi Ab Rashid, Sharifah Khadijah Syed Agil and Mezbah Uddin Ahmed. Published in the ISRA International Journal of Islamic Finance. Published by Emerald Publishing Limited. This article is published under the Creative Commons Attribution (CC BY 4.0) licence. Anyone may reproduce, distribute, translate and create derivative works of this article (for both commercial and non-commercial purposes), subject to full attribution to the original publication and authors. The full terms of this licence may be seen at http://creativecommons.org/licences/by/4.0/legalcode

This is based on commissioned research for the International Shariah Research Academy for Islamic Finance (ISRA). 


\section{Introduction}

The Sharī'ah requirements regarding the transferability of intangible assets include a clear transfer of title and the need for the asset to adhere to Shari' ah-compliance requirements, which include avoidance of gharar (uncertainty), maysir (gambling) and concealing knowledge. The avoidance of gharar is twofold: parties must know exactly what the product is as well as its precise value. However, Khattak et al. (2015) found that there is a lack of clarity with regards to rights and remedies associated with intangibles in some Islamic jurisdictions.

Bouheraoua et al. (2013) have also found important Sharīah issues related to intangible assets such as gharar fähish (excessive uncertainty) in the identification and determination of the intangible assets due to their non-physical attributes and the probabilistic nature of their future benefits. They have identified two Shari`ah views on this issue. One view does not recognize probable future economic benefits until they actually exist, to ensure the protection of property and avoid disputes among the contracting parties. The other view recognizes probable future economic benefits when the probability of their existence is preponderant.

The involvement of intangible assets in the structuring of Islamic financial products has raised emerging pertinent reporting issues of substance and form of the financial transactions. The financial reporting issues present in the accounting of intangible assets require specific accounting policies and treatment that consider Sharīah requirements on permissible, measurable, separable and tradable dimensions. This study intends to explore the reporting dimensions of intangible assets in accordance with International Financial Reporting Standards (IFRS) and the relevant Sharī' ah requirements.

\section{Objectives of the study}

To confirm and seek the consensus of expert opinions for the purpose of facilitating the formulation of appropriate policy and effective strategy for reporting intangible assets in the Islamic financial services industry, the principal objectives of the study are designed as follows:

- to highlight issues on specific financial reporting requirements on intangible assets as specified in IAS 38 Intangible Assets and relevant standards (IASB, 2016) with reference to Islamic financial transactions; and

- to elicit professional accounting and Sharī'ah expert opinion and views on the risk exposures of adopting financial reporting requirements of financial assets as economic consequences of Islamic financial transactions.

\section{Research methodology}

This study adopts a multi-method approach of content analysis of IAS 38 as well as interviews and focus group meetings with professional accountants, accounting academics and Sharī'ah scholars/advisors. Figure 1 highlights the multi-method approach.

A critical review of IAS 38 was done to highlight the pertinent dimensions of intangible assets as specified by the standard. This is followed by an in-depth interview of an audit partner familiar with Islamic banking and finance as well as two separate focus group discussions with professional accountants and accounting academics followed by regulators and Shar'̄'ah academics/scholars/advisors with significant engagement in the Islamic financial services industry in Islamic banking, takäful and Islamic capital markets. Similar interview/focus group questions were disseminated. Additional clarifications were sought 


\section{IJIF \\ 9,2}

Figure 1.

Proposed analytical framework

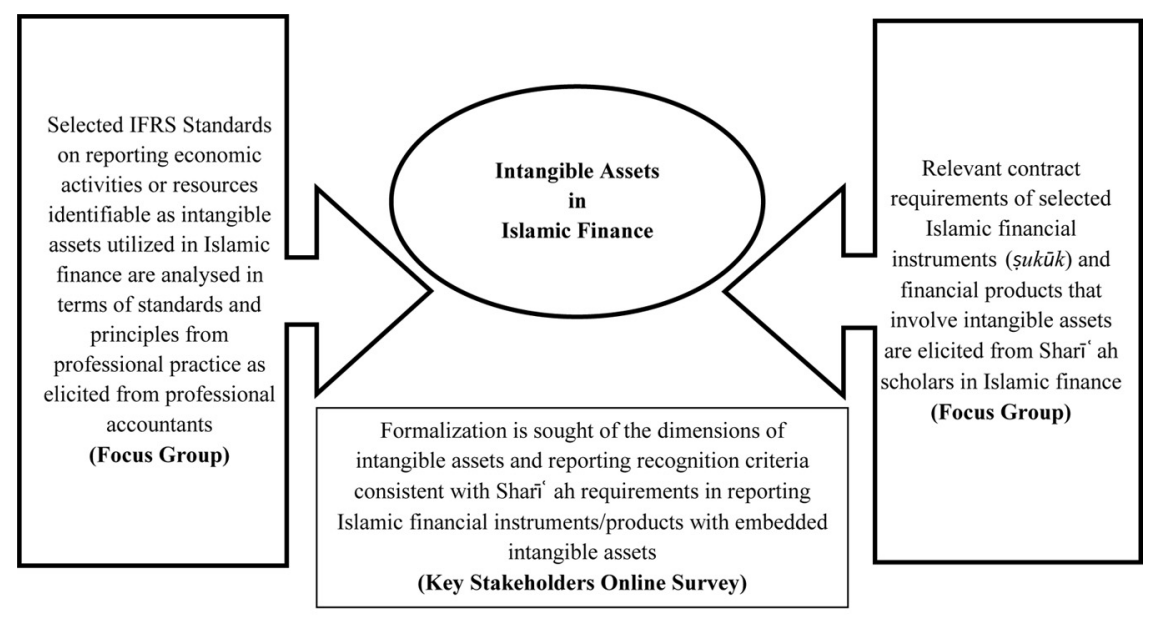

Source: Authors' own

from Sharīah focus group members to facilitate better understanding of the accounting requirements and issues.

The interview and focus group discussion responses were articulated into relevant themes to highlight particular dimensions and issues on reporting intangible assets in the Islamic financial services industry.

\section{Findings from interviews and focus group discussions}

Based on the themes derived from interviews and focus group discussions, the responses are elicited and summarized as follows:

Asset as economic resource and its value as economic consequence to investors

Both the accounting and Sharī'ah focus groups recognize assets as economic resources and acknowledge that the primary reporting purpose is to provide information to both investors and creditors and indirectly to stakeholders. Hence, economics precedes social choice in reporting based on the economic consequences in terms of asset valuation.

Intangible as non-physical substance from accounting and Sharī ah perspectives

Intangible as a concept in accounting and Sharī'ah is agreed on by members of both focus groups to represent non-physical substance. However, variations arise in terms of application of the intangible concept as an asset. Sharīah scholars view financial and monetary assets as intangibles.

\section{Importance of possession and control of intangible assets}

Both the accounting and Sharīah focus groups agree on the importance of possession and control of the asset $(m \bar{a} l)$. The Sharīah focus group distinguishes an asset $(m \bar{a} l)$ from ownership (milk) as represented and agrees that in essence, property fulfills both conditions. In accounting representation, assets include both equity and liability (obligations) claims. Hence, 
net assets as residual claims are proximate to investors' interest (ownership). This is consistent with computation of net worth in zakāh (almsgiving), which is represented by net assets.

\section{Separable as a pertinent dimension to identify an intangible asset}

The process of identification of the intangible component relates to peculiar technical or legal constructs or specifications such as recipe, patent, etc. Both focus groups agree on the need for such constructs or specifications to be identifiable. However, for the identifiable component to be reported as an intangible asset, "separable intangible component" as a dimension becomes critical. In any case, it is initiated by a management decision to identify it as a separate component and is subject to whether it is separable from tangible assets. The materiality of the intangible component is highlighted as one of the possible considerations for the need to separate.

\section{Transferable as a pertinent dimension to recognize an intangible asset}

The transferable dimension of the intangible component is pertinent to enable recognition of a separable intangible component as an intangible asset. This is significantly deliberated in both focus groups to consider both dimensions peculiar to intangibles if reported as a separate tangible asset balance sheet item.

\section{Contractual right represents both separable and transferable dimensions}

In the final analysis, due to the focus of financial reporting, the economic consequences of transactions representing contractual rights and obligations, both the accounting and Shari'ah focus groups agreed that contractual rights are paramount to recognition. These will be consistent with representing both separable and transferable dimensions. In Sharī'ah, both rights $(h a q q)$ to the asset $(m \bar{a} l)$ and rights to usufruct/beneficial use of the asset (manfa $a h$ ) are recognized. In the case of usufruct, the right to benefit could be attached to a tangible asset and hence recognized from the reporting of tangible asset lease value. On the contrary, if the intangible asset is a significant separable and transferable component, both the rights to possess, control and benefit as an asset $(m \bar{a} l)$ as well as rights to usufruct (manfa'ah) should be reported separately from tangible assets. Sharīahcompliance tests on the permissibility of activities, legitimacy and validity of contracts as well as the avoidance of usury and gharar would then be consistently applied to both the tangible asset and its intangible component or asset.

In a separate discussion of financial instruments as investments or receivables and not intangibles, the Sharī'ah focus group deliberated on the essence of intangibles being represented as monetized assets. Some șukūk issuances comprise a material (i.e. substantial) intangible component, but it is represented as financial instruments and not intangible assets. This raises an accounting issue because financial instruments are covered by IFRS 9 Financial Instruments, whereas intangibles assets are covered by IAS 38. Hence, the intangible component in such șukuk issuances may not be sufficiently disclosed in the financial statements. However, the Sharīah scholars based their judgment exclusively on the relevant sukuk information memos, which only highlight the intangible component at the issuance stage (for initial recognition). Subsequent measurement and disclosures only relate to contractual rights to receive, or obligations to disburse, cash flows as per the financial instrument standard. Both focus groups deliberated the question of whether additional disclosures on the intangible component that impacts the value of financial securities should be part of risk reporting and hence be advocated.

\section{Financial reporting of intangible assets}

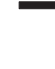



On initial and subsequent measurement of tangible and intangible asset value with certainty, both the accounting and Sharīah focus groups acknowledged the economic consequences of valuation of investors and creditors' interest. Supplementary information on the value of assets in the interest of third parties or stakeholders needs to be presented as separate disclosures. The choice of subsequent fair value measurement method(s) may require Shar'̄ ah scrutiny, especially on intangible assets affecting other external third-party interests.

Sufficiency of intangible presentation and disclosure as per IAS 38

IAS 38 only provides specific guidance on the presentation and disclosure of intangible assets. If the intangible components of a tangible asset are not treated separately, then they lack specific guidance under this standard. Hence, management discretion whether to quantify intangible assets raised concerns on the implications of social choice relating to public or stakeholder interest. The choice of reporting something as an intangible component in disclosure notes or as an intangible asset presented in the balance sheet item needs to be substantiated. Furthermore, risk-based and Sharī' ah-compliant disclosures on intangible assets as well as material intangible components of tangible assets are lacking. This is especially so in the issuance of financial instruments such as shares or șukuk. The risk characteristics of an intangible asset, or the intangible component of a tangible asset, may change over its lifecycle. This may pose challenges in reasonable valuation and disclosure, which in turn substantively complicate periodic monitoring of Shari`a ah compliance.

\section{Conclusion}

This paper concludes an interesting phenomenon on how professional accountants apply the provisions of IAS 38 and its exclusion on intangible assets and the views of Shari' 'ah scholars' in line with related requirements in Islam. The professional accountants' views appear to be premised on economic choice consideration. In other words, they are investor-centric. Sharīah scholars, on the other hand, are concerned with the social choice consideration of compliance and stakeholder interest. Though both accountants and Shari' ah scholars agree on the key dimensions of intangible asset reporting, variations arise due to a broader perception of intangible assets as including financial instruments and monetized assets. The central concern is the effect of this treatment on the contracting parties who rely on the sufficiency of the information disclosed for their informed decisions. Economic decision usefulness as propagated by the financial reporting standards in reporting intangible assets would require additional disclosures on the intangible component of tangible assets in terms of Sharíah compliance and risk-based disclosures.

\section{References}

Bouheraoua, S., Mohamad, S., Kasri, N.S. and Abdullah, S. (2013), "A critical analysis of Sharī'ah issues in intangible assets", ISRA Research Paper 61/2013, International Shari'ah Research Academy for Islamic Finance (ISRA), Kuala Lumpur.

IASB (2016), IFRS Standards (Red Book), International Accounting Standards Board, London.

Khattak, S. Lawrence, J. and Yearwood, R. (2015), "Intangibles: the next frontier of the Islamic economy", available at: www.klgates.com/files/Publication/7112b8b2-50ee-4ffa-932c8ffd90d0209d/Presentation/PublicationAttachment/7916723f-ec84-4159-be10-ffac00dbb081/ Intangibles-the_next_frontier_of_the_Islamic_Economy.pdf (accessed 18 August 2017). 


\section{About the authors}

Syed Musa Alhabshi, PhD, is currently the Dean and an Associate Professor at the IIUM Institute of Islamic Banking and Finance (IIiBF). He holds a Doctorate of Business Administration (DBA) (Accounting and Finance) (1994) from University of Strathclyde, UK and a Bachelor of Business Administration (Hons) (1989). He is engaged as a member of a few Sharíah committees serving Islamic financial institutions in Malaysia.

Hafiz Majdi Ab Rashid, PhD, is currently an Associate Professor at the Department of Accounting, Kulliyyah of Economics and Management Sciences, the International Islamic University Malaysia (IIUM). He obtained a Bachelor's in Accounting from IIUM and a Master's in Accounting and Finance and $\mathrm{PhD}$ in Accounting from the University of Lancaster. His current research interests include financial accounting and reporting in Islamic financial institutions, corporate governance and market-based accounting research.

Sharifah Khadijah Syed Agil, $\mathrm{PhD}$, is currently a Senior Lecturer at the Universiti Teknologi MARA (UiTM) Faculty of Accountancy and is also attached to the Centre of Professional Accountancy UiTM (IPAC Education) at INTEC Education College, Malaysia. She holds a Doctor of Philosophy (Accounting) from UiTM (2010) and Master's of Accountancy from the University of Glasgow (1993). She has served on the Ethics Standard Board of Malaysian Institute of Accountants (MIA) and was previously responsible for the conduct of the MIA Qualifying Examination.

Mezbah Uddin Ahmed is a Researcher at the International Shariah Research Academy for Islamic Finance (ISRA). He is also a member of the Association of Chartered Certified Accountants (ACCA) and an AAOIFI Certified Islamic Professional Accountant (CIPA). He has obtained a BSc in Applied Accounting from Oxford Brookes University, UK and an MSc in Islamic Banking and Finance (MIBF) from IIUM Institute of Islamic Banking and Finance (IIBBF), Malaysia. Mezbah Uddin Ahmed is the corresponding author and can be contacted at: mezbah@isra.my

For instructions on how to order reprints of this article, please visit our website: 